at Pasadena. During seven months in the United States, he visited many American universities and research institutes and delivered numerous discourses; in quite characteristic fashion, he scorned American public transport, and drove his own car, acquired in New York on his arrival and disposed of there on his departure, across the American continent, over a total distance of 16,000 miles. Shortly after his return, Davies was again invited to visit the United States, to address the annual meeting of the American Institute of Mining and Metallurgical Engineers, held in New York in February this year ; he had agreed to do so, and to visit other centres to renew contacts made during the previous year, but he died during the week of the meeting.

Research, though energetically and enthusiastically pursued, by no means represented the sum total of his activity. He was a teacher of unusual quality, and his lectures were invariably prepared with meticulous care and presented with superb lucidity. He was, in addition, a gifted administrator; his department was most efficiently organized, and he was, for a period, vice-principal of his College. $\mathrm{H}_{\Theta}$ had also numerous other interests quite unconnected with his academic work. $\mathrm{H}_{\Theta}$ was an accomplished musician with a particular interest in church music, and was organist and choirmaster in his own church at Aberystwyth and at the church which he attended at Cambridge; he had in his early years been an active cross-country runner and retained throughout a lively interest in all kinds of sport, his last hobby being yachting; and in his rare moments of relaxation, he was an avid reader of detective fiction.

In all the many facets of his life, he had an essential good-nature and personal eharm which brought him a host of friends, varying immensely among themselves, but united by their regard for his warm humanity and patent sincerity. The key to his character undoubtedly lay in the fact that his roots remained firmly fixed in his native Welsh soil, and he carried into the wide world the virtues implanted in him by the devout, unhurried and unpretentious atmosphere of his upbringing. I. C. JONES

The sad news of Prof. R. M. Davies's sudden death came as a shock to his many friends in the United States. He had been invited to lecture at the American Institute of Mining and Metallurgical Engineers Symposium on High-Speed Stressing of Solids in New York City on February 17. It was with great disappointment that we heard that, due to illness, it was necessary for him to cancel that visit.

He had been in the United States twice, once during the Second World War and again for the academic year 1956-57, when he was a visiting professor and lectured at the California Institute of Technology and at Rensselaer Polytechnic Institute. During this last visit, in addition, in his travel from coast to coast, he gave lectures at various universities and technical institutes.

Prof. Davies was a superb teacher, and all those who had the fortune to attend his lectures will never forget the excellence and brilliance of his presentation. As a result of his research, especially in the field of stress waves in solids, he leaves important and permanent contributions.

Those who knew R. M. Davies during the Second World War, when he was working under Sir Geoffrey Taylor at Cambridge for the Ministry of Supply, will always remember the very happy combination of 'G. I.' and 'R. M.'. His loss is particularly felt by the many who enjoyed his friendship and appreciated his warm personality, his deep Welsh sense of humour and the interest, helpfulness and understanding he always showed toward other people. These friends will realize that with the passing of R. M. Davies a very dear part of their lives has forever ended.

ENRICO Volterra

\section{Prof. T. Shimizu}

TAYei Shimrzo, who died suddenly on January 30 , was well known as the founder of the chief Japanese school of studies on steroids and especially bile acids. $\mathrm{He}$ was a pupil of the late Heinrich Wieland from 1920 until 1923, and again from 1929 until 1931, and from him returned to Japan with an enthusiasm in this field which proved lifelong.

Shimizu was born in Tokyo in 1889 and graduated from Kyoto University Medical School in 1915. He began his studies on bile acids there, under the late Prof. T. Araki. After his return from Germany in 1923, Shimizu was appointed professor of biochemistry at Okayama Medical School : he became president of this School in 1949 and, in 1952, president of Okayama University. He was elected a member of the Japan Academy in 1950, and in $1951 \mathrm{a}$ member of the German Academy of Sciences.

Much of Shimizu's scientific contribution consisted in the persistence and skill with which he and his pupils followed up the observation of Hammarsten (1898), who found the steroid alcohol, seymnol, in the bile of sharks. This ought, perhaps, to have stimulated a much wider search for unusual bile salts, but it was not until Shimizu began his work that such a search was seriously undertaken. It was then pursued with remarkable zeal : for example, 4,000 toads were used to collect 5 litres of bile ; from this were obtained interesting alcohols, finally carefully described by $\mathbf{T}$. Kazuno (Hoppe-Seylers $Z$., 266, $11 ; 1940$ ) and the bile acids trihydroxysterocholenic and trihydroxyisosterocholenic, $\mathrm{C}_{22} \mathrm{H}_{46} \mathrm{O}_{5}$, characterized by Shimizu and T. Oda (Hoppe-Seylers $Z$., 227, 74; 1934), and by Shimizu and T. Kazuno (Hoppe-Seylers $Z$., 239, $67 ; 1936)$. In later work, Y. Okasaki (J. Biochem. Tokyo, 36, 65, 77 ; 1944) collected 1.5 litres of bile from 100,200 specimens of a newt, Diemyctylus phyrrhogaster. An account of the work of Shimizu's school up to 1935 was included by him in a comprehensive book ("Über die Chemie und Physiologie der Gallensäuren", Muramato, Okayama, 1935), which he dedicated to Prof. Araki on his seventieth birthday. K. Ohta (Hoppe-Seylers Z., 259, 53 ; 1939) reviewed the work at Okayama on fish bile, and later writers have summarized the Japanese contributions up to 1955 (for example, Physiol. Rev., 35, 178; 1955).

The discoveries of Shimizu and his pupils have widened greatly the scope of chemical and physio. logical study of bile salts, and have stimulated a new awareness of the interest of biochemical species comparisons in this as in other fields.

In June 1957 Shimizu paid his last visit to Wieland, and also visited England for the first time for nearly forty years. He then, in spite of an indifferent command of English, read a paper on some of the work now being done by one of his former pupils, S. Hayakawa. He spent some time in the United States before returning to Japan.

Tayei Shimizu was a man of broad vision, good humour and modesty of character. His memory is held in affection by his friends and former pupils everywhere.
G. A. D. Haslewood 